\title{
O fałszywej świadomości językowej i językoznawczej w podręcznikach do języka polskiego z początku XXI wieku
}

Podczas zajęć z metodyki nauczania języka polskiego i praktyk śródrocznych okazywało się, że w podręcznikach i zeszytach ćwiczeń znajdują się wszelkiego rodzaju błędy, w tym błędy rzeczowe. Przyczyniają się one do powstania w procesie nauczania języka polskiego zmąconej, a nawet fałszywej świadomości dotyczącej różnych aspektów języka. Uderza ona zarówno w uczniów, jak i nauczycieli, choć w różnym stopniu, a dokonuje się między innymi właśnie za sprawą podręczników i zeszytów ćwiczeń. Ich zbadanie pod tym kątem to jedno z pilnych zadań w dydaktyce języka.

\section{Świadomość językowa, świadomość językoznawcza i świadomość językoznawcza fałszywa}

Na początku XX w. rozróżnienie myślenia językowego i myślenia lingwistycznego, zarazem naukowego, przeprowadził w szkicu z 1915 r. Jan Baudouin de Courtenay ${ }^{1}$. To pierwsze pozwala osiągnąć świadomość językową, to drugie świadomość językoznawczą. O obydwu tych typach świadomości pisze się już od pewnego czasu w polskiej lingwistyce i dydaktyce języka z przełomu

1 J. Baudouin de Courtenay, Charakterystyka psychologiczna języka polskiego, [w:] idem, O języku polskim, red. J. Basara, M. Szymczak, Warszawa 1984, s. 141. 
XX i XXI w., na przykład Tadeusz Zgółka ${ }^{2}$, Marian Bugajski ${ }^{3}$, Kordian Bakuła ${ }^{4}$ oraz prace w zbiorze Świadomość językowa ${ }^{5}$. Nie wprowadzono jednak jeszcze pojęcia fatszywej świadomości językowej i fałszywej świadomości językoznawczej, co właśnie czynię.

O samej świadomości językowej wystarczy tutaj przypomnieć za Kazimierzem Polańskim ${ }^{6}$, Andrzejem Markowskim ${ }^{7}$, Marianem Bugajskim ${ }^{8}$, że polega ona na znajomości języka rodzimych jego użytkowników, że realizuje się w wypowiadaniu sądów o języku, o jego cechach, składnikach, celach, normach, a przede wszystkim o sensowności wypowiedzi. Jeśli wypowiedź zostanie uznana za niesensowną, bezsensowną, to spotka się z odrzuceniem, podobnie jak wady innego rodzaju, na przykład w doborze wyrazów czy ich szyku. Tego rodzaju świadomość bywa zwykle intuicyjna, jeśli dojdzie do niej szczególne zaciekawienie językiem, prowadzące do zdobycia wiedzy o języku, jego budowie, historii, zróżnicowaniu, to wtedy mamy do czynienia ze świadomościa językoznawcza. W szkole tego rodzaju świadomość sprowadza się w zasadzie do wiedzy o języku, zwłaszcza jego gramatyce. $\mathrm{W}$ ostatnich kilkunastu latach nastąpiło w dydaktyce przesunięcie i zamiana: to, co od dziesięcioleci nazywało się wiedzą o języku, nazwano świadomością językową w Podstawie programowej z 2009 r.

Ta zmiana wymaga komentarza. Nie wiemy, dlaczego ona nastąpiła, gdyż autorzy podstawy nie podali nigdzie uzasadnienia. Wobec tego braku nasuwa się spostrzeżenie, że chodzi tu jedynie o „dorównanie” tendencjom z zachodu Europy, na przykład Wielkiej Brytanii, gdzie tamtejszy Narodowy Program Nauczania (National Curriculum) od 1990 roku wymaga nauczania świadomości językowej (language awareness) ${ }^{9}$. Trzeba jednak dodać, że w najnowszym wydaniu National curriculum ${ }^{10} \mathrm{z} 2013 \mathrm{r}$. ani razu nie posłużono się terminem language awareness przez cały czas obowiązkowej nauki od 5 do 16 roku życia, odpowiadający naszej szkole podstawowej i gimnazjum.

2 T. Zgółka, Kształtowanie świadomości językowej i językoznawczej w nauczaniu języka polskiego, [w:] Wiedza o literaturze i edukacja. Ksiega referatów Zjazdu Polonistów Warszawa 1995, red. T. Michałowska, Z. Goliński, Z. Jarosiński, Warszawa 1996.

${ }^{3}$ M. Bugajski, Świadomość językowa a świadomość lingwistyczna. Społeczne i naukowe potrzeby kultury języka, [w:] Mowa rozświetlona myśla, red. J. Miodek, Wrocław 1999; idem, Język w komunikowaniu, Warszawa 2006.

${ }^{4}$ K. Bakuła, Świadomość językowa - świadomość dydaktyczna, [w:] Świadomość językowa, red. J. Nocoń, A. Tabisz, „Języka a Edukacja” 3, 2014, s. 53-62.

5 Ibidem.

${ }^{6}$ Świadomość językowa, [hasło w:] Encyklopedia językoznawstwa ogólnego, red. K. Polański, Wrocław 2003.

7 A. Markowski, Kultura języka. Teoria. Zagadnienia leksykalne, Warszawa 2005.

8 M. Bugajski, Język w komunikowaniu...

9 B. Mittins, Language Awareness for Teachers, Philadelphia 1991.

$10 \mathrm{https} / /$ www.gov.uk/government/publications/national-curriculum-in-england-english-programmes-of-study/. 
Wydaje mi się, że wprowadzenie świadomości językowej zamiast wiedzy o ję$z y k u$ nie jest dobrą zmianą. Po pierwsze, dlatego że pod świadomościa języko$w q \mathrm{w}$ podstawie kryją się treści, które od dziesięcioleci składały się właśnie na wiedzę o języku / naukę o języku. Po drugie, świadomość językowa jest nazbyt metafizyczna i niezbyt wyraźna, podczas gdy wiedza o języku przez długie lata używania w dydaktyce została już dobrze określona i jest empiryczna.

Fałszywej świadomości językoznawczej nie utożsamiam po prostu z niewiedzą. Przeciwnie, ci, którzy mają fałszywą świadomość językoznawczą co do pewnych zjawisk, mają o nich wiedzę, tyle że nieprawdziwą. Jak widać, wiedza jest terminem, który lepiej nazywa zjawisko (można też rozważać stosowanie innego jeszcze terminu — znajomość języka).

Wprowadzam pojęcie fatszywej świadomości językoznawczej analogicznie do pojęcia fatszywa świadomość językowa, którym posługuje się Agneta M.L. Svalberg ${ }^{11}$ w odniesieniu do nauki języka angielskiego jako obcego (English as Foreign Language). Fałszywa świadomość językowa przejawia się zarówno u nauczycieli, jak i uczniów; także w podręcznikach. Powstaje w wyniku działania zjawiska zwanego po angielsku misleading, wprowadzenia w błąd, które na użytek tego artykułu będę thumaczył także jako omylność, omylenie. Svalberg wymienia cztery źródła omylności: 1 . wprowadzenie w błąd co do stanu rzeczy (misleading factual information); 2. omyłka co do terminu; 3. błędne objaśnienia; 4. omylenie kontekstu ${ }^{12}$. Istnienie tego rodzaju omyłek w nauczaniu języka skutkuje powstaniem błędnych wyobrażeń, błędnych przekonań (misconception) i półprawd (half-truth). Za półprawdę uznaje Svalberg na przykład powszechnie wygłaszane w szkole stwierdzenie, że język angielski ma trzy czasy: przeszły, teraźniejszy i przyszły, podczas gdy ma tylko dwa: przeszły i teraźniejszy, a dowód stanowi brak fleksyjnych form czasu przyszłego ${ }^{13}$. Autorka nie traktuje owych czterech źródeł jako typologii, nawet nie używa tego terminu. $\mathrm{Z}$ jej propozycji korzystam swobodnie i niebezpośrednio, przyjmuję inne kryteria prezentowania materiału.

Zebrane przeze mnie dane potwierdzają istnienie fałszywej świadomości językowej i językoznawczej, pokazują, że może ona w zasadzie wystąpić w każdym miejscu języka (mówiąc metaforycznie), przede wszystkim jednak w semantyce: składnikach znaczenia wyrazu (treść i zakres), zmianach znaczenia, znaczeniach nowych (neosemantyzacja), odniesieniach i definicji.

Ośrodkiem powstawania i funkcjonowania świadomości językowej oraz językoznawczej, poprawnej i fałszywej, są pojęcia. Ich kształtowanie stanowi jeden z najważniejszych obowiązków nauczyciela i nauczania, a narzędziami tego kształtowania są podręczniki i zeszyty ćwiczeń. Chodzi o to, by uczniowie rozu-

11 A.M.L. Svalberg, The problem of false Language Awareness, „Language Awareness” 10, 2001, nr 2-3, https://lra.le.ac.uk/bitstream/2381/1061/1/Svalberg-FalseLA.pdf.

12 Ibidem, s. 3.

13 Ibidem, s. 4. 
mieli pojęcia. Rozumienie przebiega w czasie (jest procesem) i jest stopniowalne (w uproszczeniu: pełne, częściowe, nierozumienie). Im więcej nierozumienia pojęć (znaczeń wyrazów), tym więcej fałszywych wyobrażeń, fałszywych przekonań dotyczących języka, rozumień opacznych, przemieszanych, pojmowań nakładających się na siebie, choć bez związku z sobą (na przykład oportunizm jako przejaw oporu). Największy udział w powstaniu fałszywej świadomości językowej i językoznawczej mają błędy rzeczowe; ich wskazanie, zanalizowanie, poprawienie zajmuje $\mathrm{z}$ konieczności niemało miejsca $\mathrm{w}$ artykule. Te czynności zastosuję teraz w przykładzie, który przybliży, ukonkretni pojęcie fałszywej świadomości językowej i jednocześnie pokaże metodę postępowania z materiałem.

$\mathrm{W}$ zeszycie ćwiczeń dla klasy szóstej — Jutro pójdę w świat ${ }^{14} \mathrm{w}$ podrozdziale Wyrazy w przeszłości i obecnie (s. 157) polecono uczniom, by z położonych naprzeciwko siebie list wyrazów połączyć wyrazy dawne z ich współczesnymi odpowiednikami. Między innymi znalazła się tu para imbryk-czajniczek. (Cały zestaw omówiono niżej). Sprawdzenie tej pary przyniosło wyniki następujące. Samuel Linde ${ }^{15}$ jeszcze nie notuje ani czaju, ani czajnika, ani czajniczka, ale notuje imbryk. W Stowniku warszawskim z 1900 roku jest Czajnik 'imbryk do herbaty, herbatnik' (przy okazji: dzisiaj herbatnik to tylko drobne, kruche ciastko) i zdrobnienie Czajniczek ${ }^{16}$. Nie ma tych wyrazów w Stowniku wyrazów obcych Michała Arcta z 1918 r., choć jest Czaj 'herbata', a także Imbryk 'naczynie do naparzania herbaty, kawy' ${ }^{17}$. W jednym z kolejnych wydań tego słownika w 1937 r. pojawia się Czajnik 'imbryk do herbaty' ${ }^{18}$. Czajnik był zapewne dość częsty w latach 20. XX w., skoro trzykrotnie został wymieniony w „Biuletynie Domu Sztuki” poz. 104 i 105 Marcolini. Czajnik z przykrywka ozdobiony kwiatami oraz poz. 121 Czajnik do herbaty, cesarskiej fabryki Aleksandra II ${ }^{19}$. Jak widać, czajniczek nie jest wyrazem nowym i trudno go uznać za współczesny odpowiednik imbryka. Obydwa wyrazy z pary imbryk-czajniczek są dawne, choć imbryk nieco dawniejszy. Również samo zestawienie imbryk-czajniczek nie wydaje się trafne. Skoro czajnik to imbryk, to para czajniczek-imbryczek byłaby stosowniejsza. Taką też parę zestawia się w Stowniku języka polskiego pod redakcją Witolda Doroszewskiego: czajniczek 'mały czajnik służący zwykle do zaparzania herbaty; imbryczek'20, opartym na nim Matym słowniku języka polskiego: imbryczek 'mały im-

${ }^{14}$ H. Dobrowolska, U. Dobrowolska, Jutro pójdę w świat. Zeszyt ćwiczeń dla szkoły podstawowej, kl. 6, Warszawa 2014.

15 S.B. Linde, Stownik języka polskiego, t. 1, cz. 1. A-F, Warszawa 1807.

16 Stownik języka polskiego, t. 1. A-G, red. J. Karłowicz, A. Kryński, W. Niedźwiedzki, Warszawa 1900, http://ebuw.uw.edu.pl/dlibra/publication?id=254.

17 M. Arct, Słownik wyrazów obcych. 27000 wyrazów, wyrażeń i przysłów cudzoziemskich, Warszawa 1918. Oparty na wydaniu szóstym z 1913 r.

${ }^{18}$ M. Arct, Stownik wyrazów obcych. 33000 wyrazów, wyrażeń i przysłów cudzoziemskich, Warszawa 1937 (wyd. 15).

19 „Biuletyn Domu Sztuki” 1, 1922, nr 17, s. 137.

20 Stownik języka polskiego, t. 1. A-Ć, red. W. Doroszewski, Warszawa 1958. 
bryk, służący zwykle do zaparzania herbaty; czajniczek ${ }^{21}$ i to samo w Stowniku języka polskiego pod redakcją Mieczysława Szymczaka ${ }^{22}$. Zatem przekazywaną uczniom wiadomość, że czajniczek jest współczesnym odpowiednikiem dawnego imbryka, trzeba uznać za omyłkę, przyczyniającą się do powstania fałszywej świadomości językowej.

\section{Przedmiot i metoda badań}

Do badania świadomości językoznawczej przejawiającej się w podręcznikach zastosowano jedną z metod empirycznych, a mianowicie obserwację. Materiału dostarczyły podręczniki szkolne i zeszyty ćwiczeń dla uczniów liceum, gimnazjum, szkoły podstawowej z lat 2000-2015 (pełne dane na końcu artykułu).

Szkoła podstawowa: Jutro pójdę $w$ świat. Zeszyt ćwiczeń, kl. 6; Słowa $z$ uśmiechem. Słowniczek ucznia klasy 4; Słowa z uśmiechem. Słowniczek ucznia klasy 5; Stowa z uśmiechem. Nauka o języku i ortografia. Cz. 2. Klasa 5; Nowe To lubię! Kształcenie kulturowo-językowe. Klasa 5; Nowe To lubię! Kształcenie kulturowo-literackie. Klasa 5; Wyspy szczęśliwe. Podręcznik do kształcenia literacko-kulturowego dla klasy czwartej; Pisanie nie jest trudne! Ćwiczenia redakcyjne dla klasy 4 szkoły podstawowej.

Gimnazjum: Gramatyka języka polskiego. Podręcznik dla gimnazjum; Gramatyka i stylistyka. Język polski kl. I; Bliżej stowa. Klasa 2; Między nami (dla klasy trzeciej gimnazjum, wersja dla nauczyciela).

Liceum i technikum: Lustra świata. Renesans - Oświecenie. Cz. 2; Zrozumieć tekst - zrozumieć człowieka. Starożytność - średniowiecze. Klasa 1, cz. 1 i cz. 2; Klucz do świata. Klasa II, część 1.

Podręcznik szkolny skupia w sobie cechy, których nie mają inne obiekty. Daje wgląd w świadomość aż trzech podmiotów. Przede wszystkim, i w największym stopniu, wyraża świadomość autora. Z kolei nauczyciel, wybierając do stosowania $\mathrm{w}$ klasie dany podręcznik, przejmuje zawartą $\mathrm{w}$ nim wiedzę (świadomość) i przekazuje ją dalej uczniom, którzy z tego podręcznika się uczą. Jego autor, nauczyciel, uczeń mają w efekcie tę samą świadomość, choć nie taką sama, bo na przykład różną co do zakresu, szerokości, stopnia. Jeśli dodać jeszcze świadomość (wiedzę) recenzenta (-ów) lub rzeczoznawców, którzy dopuścili podręcznik do druku, to krąg podmiotów wzrośnie — tym bardziej warto badać pod przyjętym kątem podręczniki. (Oczywiście, świadomość językoznawcza nauczyciela i ucznia nie sprowadza się ściśle i wyłącznie do wiedzy zawartej w danym podręczniku, ale tę okoliczność pomijam, wykracza ona poza postawione zadanie).

${ }^{21}$ Maty słownik języka polskiego, red. S. Skorupka, H. Auderska, Z. Łempicka, Warszawa 1969 (wyd. 7).

22 Stownik języka polskiego, t. 1-3, red. M. Szymczak, Warszawa 1988 (wyd. 5). 
Przejawy fałszywej świadomości obydwu rodzajów znajdowałem w różnych miejscach podręcznika, w różnych składnikach jego budowy: w wiadomościach, w poleceniach, w przykładach, w odpowiedziach. I można by z tego uczynić zasadę porządkowania danych, jednak jeszcze nie skorzystamy z tej możliwości. Znalezione w podręcznikach przykłady omylności pogrupowane zostaną ze względu na ich treść $\mathrm{i}$ włączone $\mathrm{w}$ większe przedmiotowe obszary (dziedziny): teorii komunikacji, słowotwórstwa i fleksji (w tym mylenie zjawisk fleksyjnych ze słowotwórczymi), znaczenia wyrazów (na przykład temat, lekcja), zmiany znaczenia w czasie (dawność, współczesność), zjawiska fonetyczne historyczne, jak przegłos polski, wymowa nazw własnych, definiowanie pojęć. Terminy i stwierdzenia w każdym z tych obszarów rozpatrywane będą ze względu na ich dokładność i trafność.

Z konieczności, to jest ze względu na przedmiot badania, muszą się przenikać $\mathrm{w}$ analizie i ocenie spostrzeżenia językoznawcze $\mathrm{z}$ dydaktycznymi.

\section{Dawność i nowość w języku}

Składnikiem świadomości językowej jest poczucie dawności lub współczesności czy też nowości wyrazów. Są w podręcznikach i zeszytach ćwiczeń przykłady zaburzeń tego poczucia. Stąd za neologizmy bierze się wyrazy już dawniej obecne w polszczyźnie.

W Jutro pójdę $w$ świat w podrozdziale Wyrazy w przeszłości i obecnie polecenie 97, by połączyć dawne wyrazy z ich współczesnymi odpowiednikami. Jako dawne podano między innymi: dziewczyna, trzewiki, taboret, butelka, kubrak, wiktoria, imbryk, a ich (niby) współczesne odpowiedniki to: podlotek, buty, stotek, flaszka, kurtka, zwycięstwo, czajniczek (s. $157^{23}$ ). Nawiasowe „niby” wzięło się stąd, że wyrazy podane jako współczesne są przecież stare, a zatem nie łączą się $\mathrm{w}$ opozycyjne pary $\mathrm{z}$ wyrazami określonymi jako dawne. Jedne i drugie są $\mathrm{w}$ różnym stopniu dawne ${ }^{24}$. Wyraz trzewiki określony w zadaniu jako dawny w przeciwieństwie do współczesnych butów zna i używa każda sprzedawczyni w każdym sklepie z butami, każdy producent posługuje się nim na stronie internetowej zakładu (na przykład dwóch znanych wytwórców trzewików https://www.rylko.com/pl/ katalog/trzewiki i https://wojas.pl/on/buty/trzewiki), buty znane są w polszczyźnie od XV w. Para (dawna) wiktoria-(współczesne) zwycięstwo również nietrafnie, a nawet opacznie zestawiona, bo to zwycięstwo jest starsze od wiktorii, która jako wiktoryja / viktoryja pojawiła się w XVII w. Różnica między nimi polega na tym, że wyrazu wiktoria używa się dziś rzadko, natomiast zwycięstwo powszechnie. Linde podaje przykłady w tomie szóstym z Dworzanina Łukasza Górnickiego:

${ }^{23}$ Numery stron podane w nawiasie w tekście głównym odnoszą się do omawianego w danym momencie podręcznika lub zeszytu ćwiczeń.

${ }^{24}$ O pochodzeniu omawianych tu wyrazów zob. na przykład A. Brückner, Stownik etymologiczny języka polskiego, wstęp Z. Klemensiewicz, Warszawa 1957. 
Zwycięstwo to jest największe, kto siebie sam zwyciężyć umie, i również Górnickiego Najuczciwsze szukanie zwycięstwa, dobrodziejstwy dobrodziejstwa chcieć zwyciężyć z dziełka Seneka o dobrodziejstwach ${ }^{25}$. Hasła wiktoria u Lindego nie ma.

Nietrafnie zostały zestawione pozostałe pary: stót to prasłowo, więc i stolek jest stary, flasza i flaszka dawno dotarly do nas z niemczyzny, kurtka to dawna pożyczka z węgierskiego, zdrobnienie od kurta, a podlotek w znaczeniu 'młode dziewczę, wychodzące z lat dziecinnych' odnotowano w Stowniku wileńskim $\mathrm{z} 1861 \mathrm{r}^{26}$

Zadanie trzeba uznać za całkowicie chybione. Stanowi ono jeden z najdosadniejszych przykładów fałszywej świadomości językowej, w tym wypadku dotyczącej świadomości wyrazów dawnych i ich dzisiejszych odpowiedników.

W tymże zeszycie ćwiczeń znajduje się rozdział pt. E ruchome, czyli coś, co przewiduje się $\mathrm{w}$ programach nauczania dopiero $\mathrm{w}$ liceum, zresztą tradycyjnie. Co kierowało autorkami, że zajęły się tym w klasie szóstej? Może mają rację? Dobrze byłoby poznać uzasadnienie.

Wyspy szczęśliwe $e^{27}$ zawierają pytanie o to, jacy członkowie rodziny ukryli się w podanych przysłowiach, wśród których między innymi Na dwoje babka wróżyła. Przykład to nietrafny, bo tutaj babka nie oznacza matki matki lub ojca, lecz albo w ogólności nieokreśloną starą kobietę, albo w szczególności — co bardziej prawdopodobne - zajmującą się wróżeniem. Tutaj babka nie ma nic wspólnego ze stosunkami pokrewieństwa. Widać, że w tym zadaniu współczesna świadomość językowa związana z wyrazem babka jako znaczącym kogoś z rodziny wypiera znaczenie historyczne tego wyrazu, jedynie poprawne.

\section{Pojęcia słowotwórcze}

Przejawy fałszywej świadomości językoznawczej w zakresie słowotwórstwa znajdują się w kilku podręcznikach z różnych etapów edukacyjnych. W Zrozumieć tekst - zrozumieć człowiek ${ }^{28}$ popełniono błędy rzeczowe w posługiwaniu się pojęciem rdzeń. W lekcji 57 posłużono się tym pojęciem dwa razy i dwa razy błędnie. Napisano: „zwolena - forma bierna od zwoleć (,wybrać”), dziś w polszczyźnie istnieje przekształcona postać tego słowa: woleć (tylko w wyrażeniu

25 S.B. Linde, Stownik języka polskiego, t. 6. U-Z, Warszawa 1814.

26 Stownik języka polskiego obejmujący oprócz zbioru właściwie polskich znaczna liczbę wyrazów z obcych języków polskiemu przyswojonych... Do podręcznego użytku wypracowany przez A. Zdanowicza, M. Bohusza Szyszkę, J. Filipowicza... Wydany staraniem i kosztem M. Orgelbranda. Część I A-O. Część II P-Ż, Wilno 1861.

27 G. Kulesza, J. Kulesza, Wyspy szczęśliwe. Podręcznik do kształcenia literacko-kulturowego dla klasy czwartej, Wrocław 2011.

28 D. Chemperek, A. Kalbarczyk, Zrozumieć tekst - zrozumieć człowieka. Starożytność średniowiecze. Klasa 1, cz. 1. Kształcenie w zakresie podstawowym i rozszerzonym. Podręcznik do języka polskiego dla liceum i technikum, Warszawa 2012. Dalej tytuł skrócony. 
woleć coś od czegoś), a także słowo z tym rdzeniem: zwolennik (s. 264). Z jakim rdzeniem? Ani zwoleć, ani woleć nie stanowią rdzenia w wyrazie zwolennik ani w żadnym należącym do rodziny. Rdzeniem jest -wol-. Oprócz tego zwolena nie pochodzi od zwoleć, lecz od zwolić ${ }^{29}$.

Drugie błędne użycie pojęcia rdzeń tkwi w objaśnieniu wyrazu rodzica z Bogurodzicy: „słowo rodzic z formantem tworzącym formę żeńską: - $a$; w dzisiejszej polszczyźnie nie ma możliwości utworzenia od tego rdzenia formy żeńskiej; występuje za to forma liczby mnogiej: rodzice" (s. 265). Rdzeniem nie jest rodzic, lecz rod-/rodz-. Pomylono tu zagadnienia fleksyjne (temat i końcówka) ze słowotwórczymi. Z punktu widzenia fleksji podzielimy wyraz rodzic-a, a z punktu widzenia słowotwórstwa na rodz-ica, podobnie dziew-ica, ciemn-ica, stol-ica.

W Gramatyce języka polskiego ${ }^{30}$ dla gimnazjum popełniono kilka błędów dotyczących zagadnień słowotwórczych. Na stronie 181 nietrafnie wywodzi się bezdomny wprost od dom. W części Powtórzenie i utrwalenie wiadomości ze stowotwórstwa i stownictwa źle wykonano kilka ćwiczeń. Ćwiczenie „1. Od podanych wyrazów utwórz trzy pochodne. Oddziel formanty” wykonano tak: „znać $\rightarrow$ po-znać, rozpoznać $\rightarrow$ rozpozn-anie; scena $\rightarrow$ scen-ka, scen-iczny, scen-o-grafia; gimnazjum $\rightarrow$ gimnazj-alny, gimnazjal-ista, gimnazjalist-ka" (s. 227). Rozpoznać nie pochodzi od znać, lecz od poznać; scenografia nie pochodzi jedynie od scena, lecz i od grafia; gimnazjalista nie od gimnazjum, lecz od gimnazjalny. W odpowiedzi do zadania 2 podzielono kwieci-sty (s. 227), a powinno być kwiec-isty. Polecenie 8 wymaga, by od wyrazów czytać, palić, biegać utworzyć wyrazy pochodne należące do różnych kategorii. W odpowiedzi podano: „b) czytel-nik, pal-acz, bieg-acz; c) czytelnicz-ka, palacz-ka, biegacz-ka" (s. 228), co znaczy, że od czytać utworzono błędnie czytelnik i czytelniczka, od palić — palacz i palaczka, a od biegać — biegacz i biegaczka. Poprawna derywacja wygląda następująco: czytelniczkę tworzy się od czytelnik, nie od czytać, palaczkę od palacz, a nie palić, biegaczkę od biegacz, a nie biegać.

Zachodzi uzasadniona obawa, że przytoczone przykłady zmącą, jeśli nie zafałszują, rozumienie takich pojęć językoznawczych, jak wyraz podstawowy, wyraz pochodny, rdzeń, formant.

Z kolei w zeszycie ćwiczeń Jutro pójdę w świat polecenie 102 wymaga, by w rozsypance wyrazowej uczeń znalazł pary składające się z wyrazu podstawowego i pochodnego. Zestaw wyrazów wymusza wskazanie par niepoprawnych kot-koteczek, dom-przydomowy, roślina-roślinność (s. 160). Poprawnie dla ko-

29 W. Kuraszkiewicz, Gramatyka historyczna języka polskiego. Podstawowe wiadomości z wyborem tekstów staropolskich do ćwiczeń, Warszawa 1972, s. 180; S. Urbańczyk, ,Bogurodzica”. Problemy czasu powstania i tła kulturalnego, [w:] idem, Prace z dziejów języka polskiego, Wrocław 1979, s. 134.

30 Z. Czarniecka-Rodzik, Gramatyka języka polskiego. Podręcznik dla gimnazjum kl. I-III, Warszawa 2000. 
teczek podstawowy jest kotek, dla przydomowy — przy domu, dla roślinność — roślinny.

W tymże zeszycie ćwiczeń można by wprowadzić niewielką zmianę w poleceniu 13 wymagającym uzasadnienia pisowni nazw ulic zakończonych na -wska od nazw własnych Grochów, Czerniaków i inne (s. 175). Uzasadnienie jest poprawne i aby je wzmocnić, lepiej nie mówić o zakończeniu -wska, lecz dzielić te nazwy zgodnie z ich budową słowotwórczą: Grochow-ska skoro Grochów, Czerniakow-ska skoro Czerniaków. Warto zauważyć przy okazji, że przykłady pozwalają ćwiczyć nie tylko pisownię $w$ przed $k$, ale również $o ́$ wymienne na $o$ (Grochów - Grochowska).

Przy okazji jedno zagadnienie fleksyjne. Gramatyka i stylistyka dla klasy pierwszej gimnazjum ${ }^{31}$ na początku (s. 8) zawiera schemat części mowy, w którym pojawiają się części mowy odmienne „nie przez rodzaje” i odmienne „nie przez liczby". Do językoznawczej świadomości uczniów dostają się niepotrzebnie pseudokategorie, w dodatku w schemacie chyba nazbyt karkołomnym.

\section{Komunikacja i styl}

Czy właściwie kształtowana jest świadomość dotycząca komunikacji i komunikacji językowej? Zebrane i omówione dane pokazują, że w podawanych wiadomościach, w objaśnieniach i definicjach pojęć, w poleceniach pojawiają się niedokładności, niejasności i błędy.

W części pierwszej podręcznika Zrozumieć tekst napisano „Od momentu, gdy człowiek zaczął posługiwać się mową, przekazywał nie tylko informacje o ważnych sprawach ze swojego otoczenia, ale też o własnych emocjach i oczekiwaniach [...]" (s. 28). Człowiek robił te rzeczy dużo wcześniej, zanim opanował mowę, bez słów. „Niektóre z tych informacji komunikował nieświadomie, poza własną kontrolą. Gdy na przykład zaczynał podnosić głos, rozmówca wiedział, że rośnie w nim agresja [...]" (s. 28). Słuchacz wiedział, że agresja rośnie w mówiącym (nadawcy!), tylko dlaczego ten miałby to robić - z definicji - nieświadomie. Podnoszenie głosu ma charakter niejęzykowy, lecz nie ma, nie musi mieć, charakteru nieświadomego. Nie musi być związane z agresją, lecz również z wieloma innymi stanami: wzburzeniem, oburzeniem, wzruszeniem, rozpaczą, strachem, radością itp. Zachodzi obawa, że uczeń przyjmie mylne przekonanie (fałszywą świadomość językową), iż podniesiony głos wyraża (tylko) agresję.

Ćwiczenia do tego zagadnienia przeprowadzono na przykładzie rozmowy Papkina i Cześnika w scenie 2 aktu I Zemsty. Wątpliwe jednak, czy utwory literackie są zawsze właściwie dobranym materiałem do kształtowania świadomości zarówno językowej, jak i językoznawczej. Już pierwsze ćwiczenie może sprawić

31 Z. Czarniecka-Rodzik, Gramatyka i stylistyka. Język polski kl. I gimnazjum, Warszawa 2007 (wyd. 8, 2014). 
kłopot: „1. Określ kod, którym posługują się rozmówcy, rodzaj kontaktu i kanał wzajemnej komunikacji” (s. 29). Kodem będzie zapewne język, ale czy to wystarczy, skoro wiadomo, że chodzi o utwór sceniczny. Wszak w czytanym przez uczniów fragmencie pojawiają się informacje „pokazując pistolet”, „odchodząc”, „siada po drugiej stronie stołu”, wskazujące na zachowania, działania postaci, czyli coś niejęzykowego. Rodzaj kontaktu uczniowie będą zgadywać, gdyż w wiadomościach zdefiniowano kontakt bardzo ogólnie jako „łączność między nadawcą i odbiorcą" (s. 28) bez podania przykładów tej łączności; podobnie zgadywany będzie kanał komunikacyjny, również ogólnie zdefiniowany w wiadomościach jako „sposób, w jaki komunikat dociera od nadawcy do odbiorcy” (s. 28) bez podania przykładów. Pada sakramentalne: „3. Wskaż, kto jest nadawcą, a kto — odbiorcą w przytoczonej rozmowie" (s. 29). Wszystko wskazuje na to, że dla autorów nadawcą jest Papkin, skoro on zaczyna rozmowę, a odbiorcą Cześnik. W tym momencie widać, jak założenie, by na przykładach literackich omawiać problemy nauki o języku, nie udaje się, gdyż podany przykład literacki nie spełnia twierdzeń lingwistycznych. Każdy dramat (gatunek) obala sztywne przyporządkowanie roli nadawcy jednej z postaci dramatu, a roli odbiorcy drugiej. W dramacie każda z postaci gra te dwie role zarówno na przemian, co zwykle się dostrzega, jak i jednocześnie, czego zwykle się nie dostrzega.

W rozmowie zawsze obie te role komunikacyjne odgrywa każdy rozmówca, a jeśli nie, nie ma rozmowy, jest monolog. Tak więc pytanie o to, kto jest w rozmowie nadawcą, a kto odbiorcą, ma mało sensu, gdyż każdy z rozmówców wchodzi w obie te role.

W Między nami ${ }^{32}$ w rozdziale Język jako twór społeczny napisano: „Porozumiewanie się (komunikowanie się) polega na wymianie myśli między nadawcą a odbiorcą" (s. 88). Stwierdzenie niby oczywiste, ale... Czy tylko myśli? A uczuć? A obrazów? Może zamiast technicznego nadawcy i odbiorcy lepiej napisać, że między ludźmi, a jeszcze lepiej, bo dokładniej, między mówiącym a słuchającym.

Pojawia się też niekonsekwencja w użyciu terminów język i wypowiedź. Jedną z części tego rozdziału zatytułowano 2. Funkcja komunikatywna języka (s. 88), a tuż pod napisano, że najważniejszą funkcją wypowiedzi jest funkcja komunikatywna i w jej obrębie między innymi funkcja przedstawieniowa, o której piszą, że jest dominującą funkcją języka. Oprócz tej niekonsekwencji nasuwa się wątpliwość co do tego, która funkcja jest najważniejsza — komunikatywna czy przedstawieniowa. Trwają na ten temat dyskusje. Właśnie, gdyby w podręczniku nie rozstrzygnięto tej kwestii, lecz przedstawiono ją jako dyskusyjną, to można się spodziewać, że przyczyni się to lepiej do kształtowania świadomości językowej i językoznawczej.

W Wyspach szczęśliwych do fragmentu listu młodego Miziołka do rodziców polecenie 7 a) Poszukaj i policz, ile razy Miziołek użył w swoim liście słowa „ekstra" (s. 17). Następne dwa polecenia b) i c) podsuwają myśl, że zachodzi tu ja-

32 A. Łuczak, E. Prylińska, K. Krzemieniewska-Kleban, Między nami. Język polski. Podręcznik dla klasy trzeciej gimnazjum. Wersja dla nauczyciela, Gdańsk 2011. 
kieś nadużycie tego wyrazu i podobnych, jak cool, super. Sprawdzenie tej sugestii przyniosło wynik następujący. W cytowanym fragmencie bohater użył ekstra dwa razy i - jednak — za każdym razem dobrze, poprawnie, stosownie. Na początku Na kolonii jest ekstra! i na końcu: Czy mówilem już, że na kolonii jest ekstra? (s. 16). Mamy początkową tezę i końcowe potwierdzenie tezy, wszystko zgodnie ze sztuką pisania. Ekstra. W tym jednym zadaniu co najmniej zmąceniu, jeśli nie wypaczeniu, ulega kilka pojęć: dobry styl, stosowność stylistyczna, nadużycie.

W Wyspach szczęśliwych w stałym kąciku na marginesie pt. Profesor ttumaczy zapisano: „Słowa nacechowane emocjonalnie (uczuciowo) to wyrazy, w których znaczeniu ujawniają się emocje nadawcy, a także jego stosunek do odbiorcy lub świata. Słowa mogą być nacechowane emocjonalnie pozytywnie i negatywnie" (s. 205). I o ile świadomość językoznawcza jest tu kształtowana poprawnie, o tyle stylistyczna już nie. Tak ułożone wyjaśnienie bliskie jest temu, co się na co dzień nazywa masłem maślanym. Zawiera również za dużo obcych wyrazów. Czemu ,słowa to wyrazy"? Czemu powtórzono emocjonalnie, emocjonalnie, emocje? Można prościej, na przykład: Słowa sq nacechowane uczuciowo. Wyrażaja przeżycia mówiacego, jego stosunek do ludzi i świata. To kwestia stylu. Zamiast stylu niby-naukowego proponuję styl prostszy bardziej dostosowany do zdolności umysłowych uczniów klasy czwartej.

W zeszycie ćwiczeń Jutro pójdę w świat dla klasy szóstej polecenie:

96. Przekształć niedbały komunikat w języku mówionym na staranny w języku pisanym. [...]

Kaśka! Zaczekaj, gdzie tak pędzisz?! Miałyśmy się razem przygotowywać do klasówki. Przecież była umowa dwa dni temu. Mówiłaś, że nie masz żadnych planów na dzisiaj, a teraz co? Chcesz mnie wystawić? Przecież wiesz, że nic nie kapuję z matmy... (s. 156).

Czy słusznie autorki uznały tę wypowiedź za niedbałą? Ten „niedbały komunikat" jest pod każdym względem dbały. Ma wszystko, co trzeba, także w zapisie, każdy konieczny przecinek, znak zapytania, wykrzyknik. Szkodę wyrządzają poloniści ojczystemu językowi, określając mówienie jako niedbałe i w ogóle gorsze od pisania. W ten sposób kształtuje się u uczniów fałszywą świadomość dotyczącą codziennych wypowiedzi, mówienia i relacji mówione-pisane.

W podręczniku Między nami dla klasy trzeciej gimnazjum przytoczono opowieść o tak zwanym upadku pierwszych ludzi z Księgi Rodzaju. Następnie w zadaniach dla uczniów ujmuje się postępowanie węża jako manipulację (s. 14). Czy na pewno? Wąż nie manipuluje; ujawnia wprost jasno i wyraźnie tajemnicę Jahwe. Nawet nie namawia do złamania zakazu. Bóg kłamie („,nie wolno wam jeść, abyście nie umarli”), wąż mówi prawdę: „na pewno nie umrzecie” i „otworzą wam się oczy i będziecie jak Bóg znający dobro i zło". Manipuluje ludźmi Bóg, nie ujawniając im prawdziwej przyczyny zakazu (aby nie stali się tak jak Bóg). Manipulują ludzie odpowiedzialnością przed Bogiem: mężczyzna wini kobietę, a ona węża. Nic im to nie dało, bo Jahwe uznał ich wszystkich za winnych i wszystkich ukarał. 
W Gramatyce i stylistyce na stronie 11 polecenie 4: „Według podanego planu napisz krótkie opowiadanie pt. Mój poranek. Tekst ten powinien być dynamiczny, użyj więc jak najwięcej czasowników w czasie teraźniejszym”, niewłaściwie kształtuje pojęcia stylu, opowiadania, dynamiczności, roli czasowników, roli czasu teraźniejszego w opowiadaniu. Podany plan (s. 11) jest prosty i poprawny, ale reszta już nie. Nie ,jak najwięcej”, lecz tyle ile trzeba. Niepotrzebny tekst, skoro opowiadanie. I nie tekst powinien być dynamiczny, lecz zdarzenie i opowiadanie o nim. Zgromadzenie czasowników w czasie teraźniejszym nie zapewni dynamiki, bo jeśli użyte zostaną czasowniki w czasie teraźniejszym, takie jak budze się, przeciagam się, ziewam, przymykam oczy, zasypiam ponownie, to powstanie wrażenie spokoju i rozleniwienia, czyli stanów niedynamicznych. O dynamiczności sytuacji i jej opisu decyduje charakter (sens) czasowników, a ich nagromadzenie jest czynnikiem (tylko) dodatkowym. Za lepsze uznam polecenie: Według podanego planu napisz krótkie opowiadanie pt. „,Mój poranek” tak, aby dużo się w nim działo / aby wydarzenia toczyly się dynamicznie / aby sprawiało wrażenie dynamiczności. Które wyrazy wywołują takie wrażenie? (Inną kwestią jest, czy zamiast opowiadania nie będzie lepszy opis sytuacji).

Podobne omylenia zdarzają się przy opisie przedmiotu w zeszycie ćwiczeń Pisanie nie jest trudne! dla klasy czwartej szkoły podstawowej ${ }^{33}$. Tu znajduje się zachęta, jeśli nie nakaz, by uczeń zapamiętał, że „Określenia, najczęściej w postaci przymiotników, to podstawowy element każdego opisu" (s. 31). (Stąd już tylko krok do zalecenia, by w opisach używać jak najwięcej przymiotników!). Tę zachętę poprzedza opis pajaca, bardzo rozbudowany, długi, za długi jak na klasę czwartą. Przymiotniki nie są w nim jednak najliczniejsze. Najwięcej zgromadzono tu rzeczowników. Do tego sporo imiesłowów. Powstała całość i za trudna, i sztuczna, będąca złym wzorcem gatunkowym i stylistycznym. A w umyśle ucznia powstaje świadomość, że tak należy pisać.

Dwa ostatnio podane przykłady kształtują fałszywą świadomość tego, co to jest opowiadanie (gatunek) i co to jest styl (omylne przekonanie, że jak opis, to musi zawierać jak najwięcej przymiotników).

\section{Temat lekcji i jego zakres}

Za błąd dydaktyczny i merytoryczny zarazem należy uznać stan, kiedy znaczne partie wiadomości są słabo związane z tematem lub nawet nie na temat. W efekcie powstaje fałszywa świadomość omawianych zagadnień, fałszywa wiedza o zjawiskach językowych. Przykłady tego typu pochodzą z podręcznika Zrozumieć tekst - zrozumieć człowieka już przywoływanego. Oferuje się w części

${ }^{33}$ B. Surdej, A. Surdej, Pisanie nie jest trudne! Ćwiczenia redakcyjne dla klasy 4 szkoły podstawowej, Warszawa 2014 (wyd. 8; wyd. 1, 2005). 
pierwszej (na pierwszy semestr) pięć lekcji językowych i żadna z nich nie jest bez błędu, co stwarza warunki do powstania fałszywej świadomości językoznawczej.

Temat 49 Jak korzystać z języka? nie pokrywa się z zawartością lekcji, jest wobec niej za szeroki, gdyż poświęcono ją przede wszystkim oficjalnej odmianie języka (s. 227). W treści lekcji 4 na temat „Wiesz i nie powiesz? Mowa zamiast milczenia - wypowiedź językowa jako akt komunikacji” (s. 27) nie napisano o milczeniu ani słowa, choć tak sformułowany temat tego wymaga.

$\mathrm{W}$ lekcji 40 na temat „Więcej nie powiem... Porozumienie i nieporozumienie w języku" (s. 194-196) o nieporozumieniu, jego przyczynach, skutkach, przejawach prawie nic nie napisano. Część wiadomości nie ma bezpośredniego związku z tematem lub bardzo odległy, gdyż dotyczy definiowania dialogu, monologu, polilogu, stychomytii i dystychomytii. Dla porozumienia lub nieporozumienia się ludzi nie ma znaczenia, czy przejawi się ono w dialogu, czy w monologu - może się przejawić w każdej z tych form. Dalsze partie wiadomości o prawdzie, fałszu, szczerości, kłamstwie już bardziej wiążą się z tematem, choć ściśle rzecz biorąc, należą raczej do zagadnienia „Język a wiedza o rzeczywistości” podjętego na samym końcu wiadomości w Miniprzewodniku (s. 196). Najbliżej tematu są podane reguły skutecznej komunikacji Paula Grice'a, ale nie pokazano, jak łączą się one z możliwością nieporozumienia i niezrozumienia - dopiero ćwiczenia dają taką okazję, choć tylko jedno z nich wiąże się wprost z zagadnieniem. I na dbałości o zgodność podawanych wiadomości z tematem warto by się bardziej skupić, zamiast informacji o stychomytii i dystychomytii, które są zbędne na tym etapie edukacji.

W lekcji 57 na temat „A na świecie zbożny pobyt... Trwałość i zmiana języka w dziejach" (s. 263) znajdują się błędy podobne do wskazanych. Pierwsza część tematu, będąca cytatem z Bogurodzicy, nie wiąże się treściowo z drugą częścią tematu. W wiadomościach najpierw przedstawiono pochodzenie języka polskiego. W części Dawność i nowość w języku zajęto się neologizmami i archaizmami, przy czym neologizmom poświęcono tylko jeden akapit, podając zaledwie jeden przykład neologizmu, wyraz komputer, natomiast przeważającą resztę miejsca zajęły archaizmy. Przy czym są to archaizmy pochodzące wyłącznie z Bogurodzicy. Jaką świadomość zmian w języku, dawności i nowości, życia języka ukształtuje tak przygotowana lekcja? Wąską, ograniczoną, nieproporcjonalną do dziejów języka. A przecież temat zapowiada ujęcie bardzo szerokie.

\section{Definiowanie}

Pojęcia i ich rozumienie są jednym z głównych czynników budowania świadomości we wszystkich dyscyplinach naukowych. Stąd definiowanie pojęć odgrywa szczególnie doniosłą rolę. W badanych podręcznikach znajdują się definicje niedokładne, niejasne, chybione. Trudno nie uznać, że jako takie kształtują niepożądaną fałszywą świadomość językową lub językoznawczą. 
We wspomnianej lekcji $4 \mathrm{w}$ Zrozumieć tekst autorzy używają pojęcia porozumienie tam, gdzie trafniej byłoby powiedzieć porozumiewanie, na przykład „Aby mogło dojść do porozumienia się w języku, muszą wystąpić następujące elementy [...]” (s. 27) i „Porozumienie pozajęzykowe” (s. 28), choć mowa tylko o porozumiewaniu się.

Stwierdzenie, że „przekazywanie informacji w języku to językowy akt komunikacji” (s. 27) jest prawdziwe, ale chyba jednocześnie wywołuje wrażenie, że językowe akty komunikacji sprowadza się tu do przekazywania informacji, co stanowi tylko jedną $\mathrm{z}$ wielu funkcji mówienia.

Z kolei monolog zdefiniowano jako „akt komunikacji, w którym występuje jeden nadawca, nieprzyjmujący w żadnej części tego aktu roli odbiorcy" (s. 194). Definicja tego rodzaju jest przejawem dominującego przez dziesięciolecia strukturalnego myślenia opozycjami: jeśli nadawca, to nie odbiorca, jeśli odbiorca, to nie nadawca. Takie myślenie prowadzi do błędnej definicji monologu, jak też wielu innych pojęć i zagadnień związanych z komunikacją językową, z mówieniem i pisaniem ${ }^{34}$. Przecież ten, kto wygłasza monolog, jest nadawcą własnej wypowiedzi i jednocześnie jej odbiorcą, zawsze, za każdym razem. Każdy mówiący zawsze gra dwie role komunikacyjne jednocześnie.

Według autorów Zrozumieć tekst wyraz zbożny dziś oznacza 'szlachetny', a w Bogurodzicy 'bogaty, dostatni' (s. 264). Sprawdźmy. W internetowym słowniku PWN zbożny „1. daw. »wypływający ze szlachetnych pobudek « 2. daw. »pełen powagi, skupienia «3. daw. »wypelniający obowiązki religijne«"35. Ale w słowniku pod redakcją M. Szymczaka już nie, bo tu 'zacny, bogobojny, skupiony', choć przy zbożnie 'uczciwie, szlachetnie, bogobojnie, cnotliwie'. W nieco starszym Małym słowniku języka polskiego wyraz zbożny ma znaczenia 'pobożny, nabożny; poczciwy, zacny; cnotliwy, bogobojny'. Jak widać, są różnice w definiowaniu współczesnego znaczenia wyrazu zbożny. Dla Bogurodzicy i uczniowskiej oraz nauczycielskiej świadomości znaczenia wyrazu zbożny w jego macierzystym kontekście, czyli w pieśni, decydujące są ustalenia historyków języka: zbożny znaczy 'pobożny' ${ }^{36}$. Pobożny to jednak nie szlachetny, jak podano w podręczniku. (Można dodać, że w literaturoznawczym omówieniu pieśni przyjęto ogólne i w cudzysłowie „,szczęśliwy”37).

Błąd zawiera polecenie „1. Znajdź w Bogurodzicy imiesłów bierny (inny niż sławiena), wskaż w nim ślad po przegłosie polskim” (s. 265). Tym poszukiwanym imiesłowem jest zwolena, ale nie stanowi on przykładu przegłosu, gdyż reprezentuje stan przed przegłosem. Przegłos zaszedłby dopiero w zwolona; owo $e \mathrm{w}$ zwolena przechodzi później $\mathrm{w} o \mathrm{w}$ wyrazie zwolona. Polecenie jest zatem

${ }^{34} \mathrm{Na}$ ten temat na przykład K. Bakuła, Mówione $\approx$ pisane: komunikacja, język, tekst, Wrocław 2008.

35 http://sjp.pwn.pl/.

36 Zob. A. Brückner, ,Bogurodzica”. Rozwiazanie zagadki, [w:] idem, Początki i rozwój języka polskiego, red. M. Karaś, Warszawa 1974, s. 135; W. Kuraszkiewicz, op. cit., s. 181.

37 T. Michałowska, Średniowiecze, Warszawa 2002, s. 285. 
niewykonalne i zarazem fałszujące świadomość dawnych procesów językowych; kształtuje fałszywą wiedzę o przegłosie polskim.

Czy wykonalne jest polecenie „2. Wyjaśnij, na czym polega archaiczność brzmieniowa słowa krzciciel'? (s. 265) Na jakiej podstawie uczniowie mają rzecz wyjaśnić? Ten podręcznik nie dostarcza im wiedzy, by mogli to uczynić. Wprawdzie można by przyjąć, że krzciciel jest archaiczne, bo tak się dziś nie mówi, i cała sprawa wydaje się banalnie prosta, ale z drugiej strony są regiony, gdzie $k r z$-, a nie $c h r z-$ stale jest obecne, na przykład w gwarach małopolskich krzan, krzakać.

We wstępie do Bogurodzicy podaje się, że Jan Długosz nazwał ją „pieśnią ojczystą" (carmen patrium) (s. 256). Trzeba jednak uczniom powiedzieć, że ojczysta to tyle co ojcowska - znana i śpiewana przez ojców, przodków. Niezbyt chyba szczęśliwie ujęto tę pieśń w kategoriach z teorii komunikacji. W części Nadawca i adresaci zapisano: „Bogurodzica ma formę modlitewnego zwrotu do adresatów: Maryi [...] oraz Bożyca, czyli Syna Bożego - Chrystusa. Formy nam, prosimy wskazują na nadawcę: społeczność wiernych". Nazwanie adresata$m i$ tych dwóch postaci z Nowego Testamentu brzmi sztucznie i nie wnosi nic do zrozumienia pieśni. Równie sztucznie brzmi społeczność wiernych wraz z nazwaniem jej nadawcą. Chyba lepiej po prostu: wierni (wierzący) zwracają się, modlą się do Marii i do Chrystusa. Wtłaczanie wiersza w ramy teorii komunikacji nie sprzyja kształtowaniu świadomości ani językowej, ani literackiej.

W omawianej lekcji o trwałości i zmianie języka w dziejach podano wiadomość, że język polski należy do grupy języków słowiańskich, które „mają wiele wspólnych cech systemowych oraz wiele podobnych elementów językowych" (s. 263). Nie podano przykładów wspólnych cech. Bez nich stwierdzenie pozostaje puste. Takaż świadomość.

W lekcji 58 Język jako system znaków pojawiły się nazbyt duże sprzeczności. W rubryce Wiedzieć więcej podano: „Systemem nazywamy zbiór, który charakteryzuje się następującymi cechami: 1) składa się ze skończonej liczby elementów [...]” (s. 267), a cały rozdział zaczyna się od: „Język ludzki jest systemem znaków, ponieważ składa się ze skończonej liczby podstawowych elementów: brzmień, które mogą łączyć się ze sobą i tworzyć większe całości - językowe znaki złożone" (s. 267). I od razu trzeba by dodać, że językowe znaki złożone tworzą zbiór nieskończony. Nie zgadza się z wyjściową definicją systemu i języka jako systemu wyodrębnienie trzech podsystemów: gramatycznego, leksykalnego, fonologicznego (s. 268), gdyż dwa z nich, leksykalny i gramatyczny, nie spełniają warunku skończoności. Ta zaś, ściśle biorąc, przejawia się jedynie w zbiorze fonemów.

W drugiej części podręcznika Zrozumieć tekst ${ }^{38}$ również znajdują się nieścisłości i braki mogące kształtować fałszywą świadomość językową. W lekcji 37

38 D. Chemperek, A. Kalbarczyk, Zrozumieć tekst - zrozumieć człowieka. Renesans - preromantyzm. Klasa 1, cz. 2. Kształcenie w zakresie podstawowym i rozszerzonym. Podręcznik do języka polskiego dla liceum i technikum, Warszawa 2012. 
o znaczeniach słów pada stwierdzenie, że znaczenia niedosłowne, metaforyczne nie występują w słowniku (s. 198), co jest nieprawdą. Każdy słownik języka polskiego, począwszy od Jana Mączyńskiego, notuje znaczenia metaforyczne.

W podręczniku Potęga stowa rozdział o języku jako systemie znaków zaczyna się zdaniem: „Język ludzki składa się ze znaków dźwiękowych, a w wypadku pisma - graficznych. Związek między dźwiękiem (znakiem graficznym) a tym, co on oznacza, jest umowny" (s. 22). Poprawienia wymagają wyrazy w nawiasie, powinno być: Zwiazek między dźwiękiem lub znakiem graficznym a tym [...]. Poważniejszy błąd zawiera druga część zdania pierwszego, w której stwierdza się, że język składa się w wypadku pisma ze znaków graficznych. Jednak język nie składa się ze znaków graficznych. W ogóle to, co napisane, to nie język, lecz tylko litery, pismo. Stale, nie tylko w tym podręczniku, różni autorzy utożsamiają język z pismem i na odwrót - pismo z językiem. Jedno z drugim ma tylko tyle wspólnego, że są wzajemnie przekładalne, ale nie są tym samym. To, co napisane na papierze, nie jest ani językiem, ani językiem pisanym. Już lepiej, bo dokładniej, trzeba powiedzieć, że na papierze zapisano język, na papierze język został zapisany, ale ten zapis nie jest językiem, lecz jedynie jego reprezentacją. Pismo nadal, tak jak u swoich początków, jest obrazem, rysunkiem, malunkiem.

W podręczniku Lustra świata ${ }^{39}$ ogarniającym trzy epoki, renesans, barok, oświecenie, znajduje się w Słowniku pojęć i terminów hasło mówiona odmiana języka — odmiana języka, którą charakteryzuje krótki czas, jaki upływa między wymyśleniem wypowiedzi a jej nadaniem (artykulacją) (s. 271). Tylko w tak zwanej spontanicznej wypowiedzi, a poza nią jakże często, o ile nie najczęściej, wypowiedź bywa przygotowana wcześniej, planowana, jak choćby przy zakupach codziennych (zwykle jakaś lista sprawunków: w umyśle lub na piśmie), przy kupnie biletu kolejowego: zanim kupujący wypowie się (zawrze ustnie umowę kupna-sprzedaży), najpierw ustala w umyśle gdzie, jakim pociągiem, o której i czy przy oknie, czy w środku przedziału. Szkolna praca w grupach kończy się przygotowaną wypowiedzią. Nauczyciele zwykle przygotowują swoje wypowiedzi na lekcji. Zapowiedź nauczyciela, że jutro przepyta z dzisiejszej lekcji, powoduje, że uczniowie (wszyscy? niektórzy?) przygotowują swoje wypowiedzi. Usprawiedliwienia $\mathrm{w}$ różnych sytuacjach i $\mathrm{z}$ różnych powodów (ot choćby spóźnienie się na lekcje) są zwykle przygotowane wcześniej niż chwila ich wymówienia. Planowanie zachodzi, musi zachodzić, przy takich poważnych przedsięwzięciach, jak oświadczenia wszelkiego rodzaju, zeznania, przysięgi, spowiedź i inne. Dalej nie ma co mnożyć przykładów. Cytowane określenie odmiany języka jest zbyt krótkie nawet jak na słowniczek, sprowadzone do jednej cechy. Podobnie określono pisaną odmianę języka — odmiana języka wyróżniająca się (poza realizacją za pomocą współczesnych komunikatorów) dłuższym

39 W. Bobiński, A. Janus-Sitarz, M. Pabisek, Lustra świata. Renesans - Oświecenie. Podręcznik do języka polskiego dla liceum i technikum, cz. 2. Zakres podstawowy i rozszerzony, Warszawa 2015 (wyd. 3). 
czasem między pomyśleniem czegoś a utrwaleniem myśli w piśmie (s. 271-272). Od razu nasuwa się przykład podważający powyższe: pisząc te uwagi, zabrałem się do tej czynności natychmiast, gdy przeczytałem ten artykuł hasłowy i tych parę zdań zapisałem jednocześnie prawie z myślami, jakie się nasuwały podczas czytania. Zapisywałem myśli na bieżąco. Gdyby zawsze konieczny był ów dłuższy czas, to pismo byłoby nieopłacalne, byłby to wynalazek chybiony. Oczywiście, mogą minąć lata między pomyśleniem a zapisaniem, ale tak samo może się zdarzyć między pomyślanym a wypowiedzianym. Znane są romansowe historie, kiedy kochający się ludzie zwlekają, niekiedy długie lata, z wypowiedzeniem uczuć (mniejsza o powody, na przykład nieśmiałość). Wypowiedź w rodzaju ,już dawno chciałem ci to powiedzieć" dobrze pokazuje upływ czasu między pomyśleniem a wypowiedzeniem.

Wprawdzie przy obydwu hasłach znajduje się odsyłacz do obszerniejszego omówienia na s. 249 podręcznika, jednak artykuł hasłowy nie może być aż tak zawężony, a przy tym nietrafny. Owo obszerniejsze omówienie zawiera zresztą te same błędy co przytoczone artykuły hasłowe.

W Lustrach świata objaśniono nadawca komunikatu - twórca, inicjator komunikatu (s. 271). Nadawcę objaśnia się przez twórcę, choć ten drugi wydaje się trudniejszy. Czy to w ogóle potrzebne, skoro na gruncie języka polskiego te dwa wyrazy, nadawca i twórca, są intuicyjnie zrozumiałe? Natomiast wyraz obcy inicjator nie jest łatwiejszy od polskiego nadawcy. A najważniejsze, że znaczenie wyrazu inicjator 'osoba występująca $\mathrm{z}$ inicjatywą, dająca czemuś początek' nie odpowiada znaczeniu wyrazów twórca i nadawca lub co najwyżej odpowiada w niewielkim stopniu.

W podręczniku Klucz do świata pojęcie aktu mowy objaśniono tak:

to konkretne językowe lub niejęzykowe działanie mające określony cel (związany z intencją nadawcy, na przykład poproszenie o coś, rozkazanie czegoś) oraz zamierzone lub niezamierzone skutki [...]. Aktem mowy może być zdanie, jedno słowo, a nawet gest, stąd mowa o tym, że jest on działaniem językowym lub niejęzykowym - można bowiem rozkazać komuś, żeby się uciszył, zarówno słowami: Bądź cicho!, jak i gestem wskazującego palca przytkniętego do zamkniętych ust. (s. 111)

Trudno zgodzić się na powyższe. Zgodnie z nazwą akt mowy musi być aktem mowy, a nie gestem. Gest nie jest mową, nie należy do mowy. Nie jest działaniem mownym, językowym. To prawda, że można kogoś uciszyć gestem, nie znaczy to jednak, że gest jest aktem mowy. Gest jest gestem, ruchem części ciała. Nie dźwięczy, nie ma głosek. W opisie aktu mowy w Encyklopedii językoznawstwa ogólnego i Stowniku terminów literackich nie ma tropu wiodącego do uznania gestu za akt mowy, i słusznie. Tylko metaforycznie gesty mówią.

Objaśnienie do Stepów akermańskich: przypis 2. burzany - wielkie krzaki ziela (s. 64). Takie objaśnienie nie wystarczy, a nawet wprowadza w błąd: skoro to są tylko krzaki ziela, to skąd koralowe ostrowy. W słowniku Orgelbranda burzan 'wysoka trawa stepowa' i do tego podano jego łacińską nazwę Cirsium eriophorum pozwalającą dokładnie ustalić, o jaką roślinę chodzi. Ostrożeń gło- 
wacz, w Polsce rośnie głównie w Karpatach, sięga wysokości 1,5 metra, kwiaty w koszyczku mają ciemnopurpurową barwę (stąd w sonecie są koralowe), kwitnie od lipca do września. Podobny jest do ostrożenia ${ }^{40}$ błotnego (chwast $\mathrm{w}$ roślinach uprawnych) i polnego (zwykły oset).

Podręcznik Bliżej stowa ${ }^{41}$ dla klasy drugiej gimnazjum mętnie, a nawet fałszywie przedstawia zagadnienie stylistyczne: „Język Biblii jest bardzo charakterystyczny, opiera się na rytmie i symetrii zdań” (s. 46). Czyż ,język oparty na symetrii zdań" nie powinien budzić sprzeciwu nauczycieli, użytkowników tego podręcznika? Wieloznaczność wyrazu język prowadzi na manowce, kształtuje fałszywą świadomość. Zamiast język lepszy będzie termin styl. Przy tym nie wszystkie księgi (gr. biblia) są rytmiczne.

Następnie wskazuje się, że w Księdze Wyjścia są powtórzenia, wypowiedzi o podobnej budowie składniowej, krótkie zdania, często zaczynające się od spójnika (46), po czym następuje polecenie: Jakiego charakteru nabiera zbudowany w ten sposób tekst? (To w końcu, o czym piszą autorki: o języku czy o tekście?) I do wyboru ucznia sformułowania: styl lekki, zbliżony do mowy potocznej; styl podniosły, pełen patosu, uroczysta tonacja... Widać, że zmierza się tu do stwierdzenia podniosłości i patosu. Takie stwierdzenie będzie jednak nieprawdziwe, zresztą nie potwierdzają go podane w podręczniku przykłady. Nie będziesz kradt nie jest ani patetyczne, ani uroczyste. Podobnie nakaz, by nie pożądać domu bliźniego, kobiety, sługi, wołu ani osła... Nie tylko w szkole kształtuje się fałszywe przekonanie, że wszystko, co zawierają biblia (księgi), jest podniosłe.

W podręczniku Między nami polecenie ,5. Napisz, w jakich sytuacjach niestosowne jest użycie slangu, na przykład młodzieżowego" (s. 90) wydaje się niewykonalne ma mocy podanej w tym podręczniku definicji slangu. Za jego definicyjną cechę uznano niezrozumiałość dla osób spoza środowiska. Młodzież nie ma takiego tajnego slangu. Nadto młodzież jest kategorią nazbyt ogólną, już prędzej uczniowie, studenci czy inne grupy. Zapewne młodociani przestępcy posługują się mową, tak by była jak najmniej zrozumiała dla osób spoza tego środowiska, ale nie można tego utożsamić ze slangiem młodzieżowym.

\section{Wymowa}

W Zrozumieć tekst $\mathrm{w}$ lekcji 41 pojawia się fałszywa wskazówka, by dicendi w wyrażeniu ars bene dicendi czytać jako diczendi (s. 215). W tym wypadku, jak

40 W słowniku pod red. M. Szymczaka jest ostrożnia. Pozostaję przy ostrożeniu. Tak też bio$\log$ Łukasz Łuczaj w artykule Zapomniane dzikie rośliny pokarmowe potudnia Polski - czyściec błotny, paprotka łąkowa, bluszczyk kurdybanek i ostrożeń łąkowy, 2007, s. 194, http://luczaj.com/ publikacje/2008\%20luczaj\%20bolestr\%20zapomniane.pdf.

41 E. Horwath, G. Kiełb, Bliżej słowa. Gimnazjum. Podręcznik. Klasa 2, Warszawa 2014 (wyd. 6). 
się wydaje, świadomość właściwa językowi włoskiemu wyparła wymowę właściwą łacinie.

W podręczniku Klucz do świata znajdują się błędy lub niekonsekwencje w wymowie nazwisk. Imię Eugéne Delacroix jako Edżen (s. 12), choć lepiej e:żen lub eużen. Na tej stronie jest Gericault żeriko, ale geriko na s. 125. Charpentier jako szarpatje (s. 51), a powinno być szarpãtje. Nie ma wymowy nazwisk Schiller (s. 11), Schlegel (s. 11, dopiero na s. 14), Bürger, Liszt (s. 11-12), Macpherson (s. 16-17), Ingres (s. 17, trudna wymowa egr lub ejgr), Boccherini (s. 41), Richardson (44), Klopstock (45), Redgrave (81), Füssli (s. 122-123), Corneille i Racine (s. 139). Inne nazwy, na przykład Collège de France (s. 162-163) i twist (41), także bez wymowy.

Wymowa szwankuje również w Nowym To lubię! ${ }^{42}$ dla klasy piątej w kształceniu kulturowo-literackim: Mark Twain jako tten (s. 15), choć raczej ttain, Tudor jako tjudor, choć raczej tju:də, Sawyer jako sojer (s. 114), a raczej səjə; Humpty Dumpty jako hampty dampty (s. 46), a powinno być hampti dampti a nawet $\operatorname{dam}(p) t i$, gdzie nawias pokazuje osłabioną wymowę $p$; Camille Claudel — camil klodel (s. 49), ale bez zaznaczenia akcentu na ostatniej sylabie, a imię wymawia się raczej kamij niż kamil. Nie podano wymowy nazwisk: Murillo, Dürer, Rodin, Tolkien, Lear.

Wymowa obcych wyrazów przyczynia się do powstania świadomości językowej. Na przykład uzmysławia podobieństwo języków lub różnice między nimi, może wywołać nawet poczucie dziwności. Usłyszane podobieństwo kształtuje świadomość przynależności, a usłyszane różnice świadomość nieprzynależności do danej rodziny językowej.

\section{Uwagi końcowe}

Wskazane i skomentowane fragmenty podręczników i zeszytów ćwiczeń mogą przyczyniać się do powstania u uczniów fałszywej świadomości językowej lub językoznawczej przez to, że zawierają: błędne przykłady; niedokładne definicje; uproszczone i błędne objaśnienia; niepotrzebne nazywanie starych treści nowym terminem (świadomość językowa v. wiedza o języku). (To wyliczenie częściowo odpowiada wspomnianym na początku źródłom powstawania fałszywej świadomości językowej wymienionym przez Svalberg).

Spośród dostępnych na rynku stosowanych w szkole podręczników tylko część została przebadana, wobec czego prawdopodobne wydaje się stwierdzenie, że w tych pozostałych podręcznikach też znajdują się przejawy fałszywej świadomości językowej i językoznawczej. Zatem zjawisko jest szersze i większe, niż to wynika z przedstawionego materiału. Jednak przedstawiony przegląd nie

42 Z.A. Kłakówna, M. Jędrychowska, K. Wiatr, Nowe To lubię! Podręcznik do języka polskiego. Kształcenie kulturowo-literackie. Klasa 5, Kraków 2007. 
powinien prowadzić do uogólnionego i pochopnego przekonania, że przeważają podręczniki i zeszyty ćwiczeń nieudane, nieprzemyślane. W większości kształtują one poprawną świadomość językową i językoznawczą.

Niemniej pozostaje jeszcze wiele do wyczytania, do sprostowania i opisania. Także przez studentów. I właśnie w pracy ze studentami widać okazję do pozytywnego wykorzystania znalezionych błędów, na przykład w ten sposób, że staną się one materiałem do ćwiczeń, referatów i prac magisterskich. Korzyść najpierwsza i najważniejsza z tego artykułu, jakiej można się spodziewać, to ta, że autorzy podręczników i zeszytów ćwiczeń oraz wydawcy poprawią je w kolejnym wydaniu, co leży w interesie samych autorów, oczywiście uczniów i nauczycieli oraz dydaktyki języka polskiego.

Widać dwie przyczyny zjawiska: zbyt szybka produkcja podręczników i złudzenia poznawcze, omyłki poznawcze, a może nawet przyzwolenie na błąd. Złudzeniem jest na przykład przekonanie, że niektóre wyrazy, jak klawiatura czy buda 'szkoła', są neologizmami. Złudzenie lub omyłka wynika z powierzchownej wrażeniowości: skoro klawiatura łączy się komputerem, to musi być nowa, jako że komputer jest nowy. Zapomina się przy tym o dość długiej historii przedmiotu i o kilku jej rodzajach (kilka instrumentów muzycznych ma klawiaturę). Z kolei składnikiem przyzwolenia na błąd będzie nieuważne czytanie podręczników złożonych w wydawnictwach przez osoby współodpowiedzialne za dopuszczenie do druku, to jest przez recenzentów, rzeczoznawców, redaktorów wydawnictwa.

Uchronić nas może kształcenie i uprawianie krytycznego czytania i myślenia, w tym krytycznej świadomości językowej i językoznawczej nie tylko wobec zjawisk językowych (na przykład manipulacji słownej), lecz także wobec samej świadomości, na przykład wobec tego, że ktoś może mieć fałszywą świadomość językową lub językoznawczą, co trzeba by sobie w końcu uświadomić.

\section{Podręczniki}

Bobiński W., Janus-Sitarz A., Pabisek M., Lustra świata. Renesans - Oświecenie. Podręcznik do języka polskiego dla liceum i technikum, cz. 2. Zakres podstawowy i rozszerzony, Warszawa 2015 (wyd. 3).

Chemperek D., Kalbarczyk A., Zrozumieć tekst - zrozumieć człowieka. Starożytność - średniowiecze. Klasa 1, cz. 1. Kształcenie w zakresie podstawowym i rozszerzonym. Podręcznik dla języka polskiego dla liceum i technikum, Warszawa 2012.

Chemperek D., Kalbarczyk A., Zrozumieć tekst_zrozumieć człowieka. Renesans - preromantyzm. Klasa 1, cz. 2. Kształcenie w zakresie podstawowym i rozszerzonym. Podręcznik do języka polskiego dla liceum i technikum, Warszawa 2012.

Czarniecka-Rodzik Z., Gramatyka języka polskiego. Podręcznik dla gimnazjum kl. I-III, Warszawa 2000.

Czarniecka-Rodzik Z., Gramatyka i stylistyka. Język polski k1. I gimnazjum, Warszawa 2007 (wyd. $8,2014)$.

Dobrowolska H., Dobrowolska U., Jutro pójdę w świat. Zeszyt ćwiczeń dla szkoły podstawowej, kl. 6, Warszawa 2014. 
Drabik B., Pstrąg J., Zawadzki A., Klucz do świata. Podręcznik do języka polskiego. Szkoły ponadgimnazjalne. Zakres podstawowy i rozszerzony. Klasa II, część 1, Warszawa 2008.

Horwath E., Kiełb G., Bliżej słowa. Gimnazjum. Podręcznik. Klasa 2, Warszawa 2014 (wyd. 6).

Horwath E., Żegleń A., Słowa z uśmiechem. Nauka o języku i ortografia. Język polski. Cz. 2. Klasa 5, Warszawa 2013 (wyd. 2, 2014)

Kłakówna Z.A., Steczko I., Wiatr K., Nowe To lubię! Podręcznik do języka polskiego. Kształcenie kulturowo-językowe. Klasa 5, Kraków 2007.

Kłakówna Z.A., Jędrychowska M., Wiatr K., Nowe To lubię! Podręcznik do języka polskiego. Kształcenie kulturowo-literackie. Klasa 5, Kraków 2007.

Kulesza G., Kulesza J., Wyspy szczęśliwe. Podręcznik do kształcenia literacko-kulturowego dla klasy czwartej, Wrocław 2011.

Łuczak A., Prylińska E., Krzemieniewska-Kleban K., Między nami. Język polski. Podręcznik dla klasy trzeciej gimnazjum. Wersja dla nauczyciela. Gdańsk 2011.

Surdej B., Surdej A., Pisanie nie jest trudne! Ćwiczenia redakcyjne dla klasy 4 szkoły podstawowej, Warszawa 2014 (wyd. 8).

\section{Słowniki}

Arct M., Stownik wyrazów obcych. 27000 wyrazów, wyrażeń i przysłów cudzoziemskich, Warszawa 1918.

Arct M., Stownik wyrazów obcych. 33000 wyrazów, wyrażeń i przysłów cudzoziemskich, Warszawa 1937 (wyd. 15).

Brückner A., Słownik etymologiczny języka polskiego, wstęp Z. Klemensiewicz, Warszawa 1957.

Głowiński M., Kostkiewiczowa T., Okopień-Sławińska A., Sławiński J., Słownik terminów literackich, red. J. Sławiński, Wrocław 2008 (wyd. 5 bez zmian).

Linde S.B., Stownik języka polskiego, t. 1, cz. 1. A-F., Warszawa 1807.

Linde S.B., Stownik języka polskiego, t. 6. U-Z, Warszawa 1814.

Mały stownik języka polskiego, red. S. Skorupka, H. Auderska, Z. Łempicka, Warszawa 1969 (wyd. 7).

Stownik języka polskiego, t. 1. A-Ć, red. W. Doroszewski, Warszawa 1958.

Stownik języka polskiego, t. 1-3, red. M. Szymczak, Warszawa 1988 (wyd. 5).

Słownik języka polskiego obejmujący oprócz zbioru właściwie polskich znaczna liczbę wyrazów z obcych języków polskiemu przyswojonych... Do podręcznego użytku wypracowany przez A. Zdanowicza, M. Bohusza Szyszkę, J. Filipowicza... Wydany staraniem i kosztem M. Orgelbranda. Część I A-O. Część II P-Ż, Wilno 1861.

Słownik języka polskiego, t. 1. A-G, red. J. Karłowicz, A. Kryński, W. Niedźwiedzki, Warszawa 1900, http://ebuw.uw.edu.pl/dlibra/publication?id=254.

\section{Bibliografia}

Bakuła K., Mówione $\approx$ pisane: komunikacja, język, tekst, Wrocław 2008.

Bakuła K., Świadomość językowa — świadomość dydaktyczna, [w:] Świadomość językowa, red. J. Nocoń, A. Tabisz, „Języka a Edukacja” 3, Opole 2014, s. 53-62.

Baudouin de Courtenay J., Charakterystyka psychologiczna języka polskiego, [w:] idem, O języku polskim, red. J. Basara, M. Szymczak, Warszawa 1984, s. 139-225.

Bolitho R., Carter R., Hughes R., Ivanić R., Masuhara H., Tomlinson B., Ten questions about language awareness, „ELT Journal” 57 (3), 2003, s. 251-259.

Brückner A., ,Bogurodzica”. Rozwiąanie zagadki, [w:] idem, Początki i rozwój języka polskiego, red. M. Karaś, Warszawa 1974. 
Bugajski M., Język w komunikowaniu, Warszawa 2006.

Bugajski M., Świadomość językowa a świadomość lingwistyczna. Spoleczne i naukowe potrzeby kultury języka, [w:] Mowa rozświetlona myśla, red. J. Miodek, Wrocław 1999.

Encyklopedia językoznawstwa ogólnego, red. K. Polański, Wrocław 2003 (wyd. pierwsze 1993).

Kuraszkiewicz W., Gramatyka historyczna języka polskiego. Podstawowe wiadomości z wyborem tekstów staropolskich do ćwiczeń, Warszawa 1972.

Łuczaj Ł., Zapomniane dzikie rośliny pokarmowe południa Polski - czyściec błotny, paprotka łąkowa, bluszczyk kurdybanek i ostrożeń łąkowy, http://luczaj.com/publikacje/2008\%20luczaj\%20 bolestr\%20zapomniane.pdf.

Markowski A., Kultura języka. Teoria. Zagadnienia leksykalne, Warszawa 2005.

Michałowska T., Średniowiecze, Warszawa 2002.

Mittins B., Language Awareness for Teachers, Philadelphia 1991.

Podstawa programowa z komentarzami, t. 2. Język polski w szkole podstawowej, gimnazjum i liceum, MEN, Warszawa 2009.

Svalberg A.M.L. The problem of false Language Awareness, „Language Awareness” 10, 2001, nr 2-3, https://lra.le.ac.uk/bitstream/2381/1061/1/Svalberg-FalseLA.pdf.

Świadomość językowa, red. J. Nocoń, A. Tabisz, Opole 2014.

Urbańczyk S., „Bogurodzica”. Problemy czasu powstania i tła kulturalnego, [w:] idem, Prace z dziejów języka polskiego, Wrocław 1979.

Zgółka T., Ksztaltowanie świadomości językowej i językoznawczej w nauczaniu języka polskiego, [w:] Wiedza o literaturze i edukacja. Księga referatów Zjazdu Polonistów Warszawa 1995, red. T. Michałowska, Z. Goliński, Z. Jarosiński, Warszawa 1996. 